\title{
THE COVERAGE OF EU-TURKEY REFUGEE DEAL IN TURKISH ONLINE PRESS
}

\author{
Nurhan KAVAKLI \\ Üsküdar University, Turkey \\ https://orcid.org/0000-0002-5003-9996 \\ nurhankavakli@gmail.com
}

\begin{abstract}
Turkey has played a significant role as a shelter for Syrian refugees whose number in the country has reached almost 3 million, the largest Syrian refugee population in the world. As a result of Turkey's geographical and political position in Syrian migration issue and along with the in the face of the overwhelming flow of smuggled migrants and asylum seekers from Turkey to Greece, in 2016 Turkey and the EU signed the Refugee Deal which aims to stop irregular arrivals from Turkey to Greek islands by allowing Greece to return to Turkey those migrants. However, the deal has raised many concerns and questions from especially some Turkish and international institutions and rights groups. Among those questions are its fairness for migrants and asylum seekers, its legality, its ethics and its feasibility. In this context, taken into consideration that the news media has an impact on forming of public opinion so that on policy outcomes and implementation, this study aims to examine the coverage of the EU-Turkey Refugee Deal in the Turkish online press. More particularly, the study is concerned with the actors and the frames which are dominantly present in the news, in order to trace how the deal has taken on meaning in public debate. In order to achieve this purpose, this study examine the news about the deal that was posted on the websites of Hürriyet, Milliyet and Cumhuriyet between 20 March and 20 July 2016 by using both content analysis and frame analysis.
\end{abstract}

Keywords: The EU-Turkey Refugee Deal, Turkish online press, political communication, Syrians refugees, international migration

\section{AB-TÜRKIYYE MÜLTECİ ANLAŞMASININ ÇEVRIMIÇi̇ TÜRKÇE HABERLERDEKİ SUNUMU}

\section{$\ddot{\mathbf{O Z}}$}

Topraklarında yaşayan üç milyonu aşkın Suriyeli mülteciyle dünyadaki en fazla Suriyeli mülteci nüfusuna sahip olan Türkiye mülteciler için önemli bir sığınak rolü üstlenmiştir. Suriyeli mültecilerle ilgili politik ve coğrafi konumlanmasının yanı sıra Türkiye'den çıkarak Yunanistan üzerinden AB'ye kayıt dışı geçiş yapmaya çalışan mülteci sayısındaki büyük artış, düzensiz göçü engellemek isteyen AB ile Türkiye arasında 2006 yılında bir göç anlaşması yapılmasına neden olmuştur. Ancak, anlaşma aynı zamanda ülke içinden ve dışından başta hak odaklı kurumların ve grupların eleştirilerine yol açmıştır. Anlaşmanın mülteciler ve sığınmacılar için ne derece adil olduğu, uygulanabilir bir anlaşma olup olmadığı ve yasal geçerliliği tartışmaya açılan sorular arasındadır. Haber medyasının kamuoyunun biçimlenme sürecinde olduğu gibi politikaların ortaya çıkma ve uygulama süreçlerinde de etkisi olduğu noktasından hareket eden bu çalışma, AB-Türkiye Mülteci Anlaşması'nın çevrimiçi Türkçe haberlerdeki sunumunu incelemeyi amaçlamaktadır. Anlaşmanın kamuoyundaki tartışmalarda nasıl anlamlandırıldığı ya da anlam kazandırıldığıyla ilgilenen bu çalışma, özellikle incelenen haberlerde hangi aktörlerin ve çerçevelemelerin daha baskın olduğunun incelenmesine odaklanmıştır. $\mathrm{Bu}$ doğrultuda, Hürriyet, Milliyet ve Cumhuriyet gazetelerinin web sitelerinde anlaşmayla ilgili olarak 20 Mart- 20 Temmuz 2016 tarih aralığında yayınlanan haberler içerik ve çerçeve analizi yöntemiyle incelenmiştir.

Anahtar Kelimeler: AB-Türkiye Mülteci Anlaşması, çevrimiçi Türkçe basın, siyasal iletişim, suriyeli mülteciler, uluslararası göç 


\section{INTRODUCTION}

On March 18, 2016, Turkey signed the EU-Turkey Refugee Deal with the European Union. At its core, the agreement aims to stem migration and refugee flows to Greece which has become a back door to the EU for illegal immigrants. According to the agreement Turkey would accept the return of all "new irregular migrants" who arrived after March 20 by travelling through Turkey. In exchange, EU Member States would increase resettlement of Syrian refugees in Turkey, accelerate visa liberalization for Turkish nationals, and boost existing financial support for Turkey's refugee population. The EU also would provide for the resettlement of one Syrian refugee from Turkey for each Syrian refugee returned to Turkey. However, the EU-Turkey Deal has raised concerns in and out of Turkey about whether the deal is fair for asylum seekers and refugees whose lives would be most affected by the deal. Addition to these concerns, issues have been raised regarding the feasibility of the deal, the legality of deal and the ethics of the deal.

Taking into consideration that news media playing a crucial role in the formation of public opinion and the social or political decision making progress, this article focuses on how the EU-Turkey Refugee Deal has been covered in Turkish online press. The way how the media describe and represent migration matters in terms of how the public perceive, define and react to it. Particularly, the news media matters much more since it has a claim to be speaking the truth to power and representing the events happening in the word to citizens (Chalaby, 1998). News media's role is not limited to having influence on public attitudes toward issues such as immigration. It also reflects those attitudes in news (Berry et al. 2015). Thus, news media has a strong potential to carry public ideas and attitudes to policy makers which means that it could make a considerable impact on policy outcomes.

However, although the relation between media coverage and public opinion is widely accepted in literature in communication and political science, whether the media's influence on the creation of public opinion and policy outcomes is an independent one is a controversial issue (Baum and Potter: 2008). For example, Stuart Hall who recognize news media as an active player in the construction public's understanding of what events mean (1997), says that this understanding depends on social positioning in the interpretation of news by different social groups (1980). Some political science scholarships believe that the media just a passive carrier of powerful elite views to the public (e.g., Jentleson 1992, Brody 1991, Zaller \& Chiu 2000, Bennett et al. 2006), while others insist on the media's powerful influence on formation of political opinions (Kuypers 1997, Graber 2002, Paletz 2002). There are also other scholars who claim that media, public opinion and policy outcomes are interdependent actors and should be taken consideration together (Nacos et al. 2000, Holsti 2004). The mass media is also considered playing a critical role alongside citizens and elites in shaping the public's attitudies, and influence foreign policy (Baum and Potter: 2008).

In this framework, this article examines three Turkish online newspapers' coverage of the EU and Turkey Refugee Deal during a three-month period. For the analysis, Hürriyet, Milliyet and Cumhuriyet newspapers are chosen for being influential papers in terms of reaching out to more people with a large variety of social backgrounds. The media coverage of the deal is examined through the frames used by actors present in the news. The idea behind that is that events gain meanings in public debate as a result of struggle over their definitions which are shaped by how actors frame them (Gamson and Wolfsfeld, 1993). Therefore, the analysis focuses more specifically on identifying the prominent actors in the news and how they frame the deal.

One point, however, should be mentioned before passing the next part of the article; Now, it has been more than a year since the agreement was put into practice and the debate over the agreement has subsided considerable. The EU has not delivered its long-promised visa free travel for Turkish nationals to the EU countries. The EU claims that Turkey has not fulfilled the agreement condition which is the complementation of 72 criteria that include the revision of Turkish terror law. In response, Turkey says "it is not possible to make such changes in regulations while Turkey is under terror attacks". 


\section{THE EU-TURKEY REFUGEE DEAL}

Turkey which has emerged as a 'gate kepeer' in the Syrian refuge crises that one of the biggest crises of the EU has faced, (Sirkeci, 2016) has been placed on the center of the issue with the EU-Turkey Refugee Deal. This agreement brings a fast-track border procedure that means all irregular refugees and migrants crossing the Aegean from Turkey to the Greek islands after 20th March 2016 are sent back to Turkey. It also means that those refugees and migrants to be sent back to the countries of origin by way of Turkey. The date of the beginning of taking back is decided as 4th April 2016. Besides, with this agreement, the EU promises to give additional financial support for the Syrians in Turkey. However, one of the most important terms of the agreement about the refugees is the "fasttrack border" procedure which is already mentioned above. That procedure is designed to be implemented to all refugees who are caught in the border region. According to this, all refugees who are caught in the border region might be the subject of readmission application by Greece in three days time. It is set forth that only "the refugees who apply and meet asylum criteria should not be affected from this situation"1.

An important part of the agreement for the relations of Turkey and the EU is that revision of some arrangements towards Turkey, who is still in the process of EU membership application, has done under this agreement. Accordingly, the predetermined starting date for visa exemption for Turkey is brought forward. The EU promised to abolish the visa for the Turkish citizens in the end of June 2016 at the latest. However, on the other hand, Turkey has been asked to complete the 72 criteria for the membership to the European Union. As of this moment when this study is being done, although Turkey completed most of these criteria, all of them could not be completed. Among the lacking criteria are collaboration with the EU about criminal cases, collaboration with European Police (Europol), standardization of Information Protection Law in accordance with EU, and redefinition of terror. Especially the changes wanted about terror were met with resistance by Turkey on account of the fact that "the country is under massive terror threat".

\section{METHODOLOGY}

In order to examine the news coverage of the deal, three online Turkish newspapers' coverage of the Deal during a three-month period (20 March- 20 July 2016) was analyzed. For the analysis, Hürriyet, Milliyet and Cumhuriyet newspapers were chosen for being influential papers in terms of reaching out to more people with a large variety of social backgrounds. Both content analysis and frame analysis were used to trace (1) what actors are present and, (2) how actors frame the agreement. We choose the examine the news media coverage of the deal through the frames used by actors in the news since "Frames provide cognitive cues that define what an issue about how it should be understand, and what actors should do about it (Statham and Trenz, 2013: 126-127). The tie between actor frames and how an issue to take on meaning in public debate could be explained by the idea "that events do not speak for themselves, but take on political meaning and significance as a result of a struggle over their public interpretation that is shaped by how actors frame them in the claims they make in public debates" (Gamson and Wolfsfeld 1993: 118). In other words, actor frames could have a widening or narrowing effect on how that issue is perceived, defined and discussed in public opinion (e.g. Benford and Snow, 2000; Gerhards and Schafer, 2010).

\section{FINDINGS}

\section{THE MAIN ACTORS IN THE NEWS}

This part, which aims to put forward the most visible actors and their frequencies in the news coverage, specifies four main actor groups based on the common characteristics of actors which are given below. Next, the data about the frequency of the actors are presented in Table 1 .

Migrants, Refugees, Asylum Seekers: They are the target groups of the agreement and they are also the ones to be directly affected by the agreement.

\footnotetext{
${ }^{1}$ For detailed information about the agreement see also Ekinci M.U. (2016). Basic Questions and Answers about Turkey-EU Exemption Process and Readmission Agreement: TR Ministry of European Union.
} 
Center of Politics: This group includes politicians and officials who are directly in decision-making positions regarding to the agreement and applicable policies.

Civil Society (periphery of politics): They are the actors who may affect or who may be affected by the agreement indirectly.

Other

Table 1.

Actors in online news

(in \%)

\begin{tabular}{|c|c|c|c|}
\hline & Cumhuriyet & Milliyet & Hürriyet \\
\hline Center of politics & 57 & 66.6 & 70.8 \\
\hline$E U$ & 10 & 21.11 & 24.2 \\
\hline Turkish politicians (Executive) & 13.8 & 16.6 & 14.5 \\
\hline Turkish politicians (Legislative) & 8.6 & 2.2 & 3.2 \\
\hline Greek politicans (Executive) & 6.9 & 6.6 & 4.8 \\
\hline Greek politicans (Legislative) & 1.7 & - & - \\
\hline German politicans (Executive) & 8.6 & 7.7. & 14.5 \\
\hline German politicans (Legislative) & - & 1.1 & 4.8 \\
\hline European Consey, UN & 6.9 & 6.6 & 1.6 \\
\hline Other & - & 4.4 & 3.22 \\
\hline Civil Society (periphery of politics) & 29.4 & 24.2 & 14.6 \\
\hline $\mathrm{NGO}$ & 22.4 & 9.9 & 8 \\
\hline Volunters/healt staff/civil servants & - & 7.7 & 1.6 \\
\hline Journalists & 6.9 & - & 1.6 \\
\hline Turkish-Greek people/citizens & - & 2.2 & 3.2 \\
\hline Migrants/refugees/asylum seekers & 10 & 8.8 & 14.5 \\
\hline in Turkey & - & 4.4 & 9.7 \\
\hline in Greece & 10 & 4.4 & 4.8 \\
\hline Other & 3.6 & 4.4 & - \\
\hline Total & 100 & 100 & 100 \\
\hline
\end{tabular}

The actor group who was mostly seen in all three newspapers is "the center of politics". The most prominent actors in this group are from the European Union. Members of Turkish government, members of German government and members of Greece government come after them. The second most visible actor group is "civil society". NGOs come to the forefront among them when we look at 
the percentage. Refugees/asylum seekers/ immigrants, however, are placed at the bottom as they become the least apparent group.

\section{HOW ACTORS FRAME THE AGREEMENT}

This part aims to find out what actor frames have been mostly used in the coverage of the deal. However, before analyzing the frames, in order to get an idea what the dominant topics in the coverage were, the most frequently used words in the news were detected and then counted how many times they appeared in the news. The most common words and their frequencies are presented below in Table 2.

Table 2. The words most frequently used in the news coverage

\begin{tabular}{|c|c|c|c|}
\hline & Cumhuriyet & Milliyet & Hürriyet \\
\hline Visa & 32 & 37 & 50 \\
\hline Passport & 3 & 5 & 3 \\
\hline Criteria & 11 & 17 & 18 \\
\hline Terror & 16 & 16 & 11 \\
\hline Freedom of the press & $13-$ & & 2 \\
\hline Human rights & 5 & 1 & 3 \\
\hline Freedom of expression & 2 & 2 & 2 \\
\hline Refugee rights & $1-$ & & 1 \\
\hline Asylum & 4 & 10 & 2 \\
\hline Death & 3 & 3 & 3 \\
\hline Protest & 1 & 1 & 1 \\
\hline Suicide & 1 & 1 & 1 \\
\hline Poor conditions & 2 & 1 & 1 \\
\hline Shame & 1 & 1 & 1 \\
\hline Unlawfulness & 5 & 5 & 1 \\
\hline Total & 300 & 319 & 233 \\
\hline
\end{tabular}

As it can be seen in Table 2, the most common used word in all three newspapers is "visa". Besides, the frequency of it is dramatically much more than the other words. The second most frequent words are "criteria" and "terror". The third one is "asylum". Starting from this grading it can be said that the most dominant topic in the coverage of the deal is visa exemption as the agreement is reported in the news mainly in relation to visa exemption. It is also possible to make the same assumption by looking at the second most frequent words are "criteria" and "terror". The criterion that Turkey has to fulfil in order to get visa exemption is about "terror regulation", which is also a point of contention between the EU and Turkey.

It can also be said that the third most frequent word "asylum" points out a situation that occurred in the implementation phase of the deal. Within this context, it can be commented that the refugees' asylum request to Greece "in order not to be sent back to Turkey" was among the dominant topics in 
the coverage. However, the number of words which can be directly related to the refugees such as "refugee rights", "death", "protest", and "poor conditions" is rather few.

\section{THE ACTOR FRAMES USED IN THE NEWS}

The coding scheme used for actor frames analysis consists of five main actor frame categories which are "an agreement on visa liberalization", "an agreement difficult to apply in practice", "an agreement not beneficial for refugees", "a problematic agreement in terms of law and ethics", "a self-abnegation agreement for Turkey". Only one of them, "an agreement on visa liberation" is divided into three sub framing groups in order to deepen the analysis.

\begin{tabular}{|c|c|c|c|}
\hline & Cumhuriyet & Milliyet & Hürriyet \\
\hline An agreement on visa liberalization & 58 & 50 & 65 \\
\hline A successful agreement for Turkey & 9 & 27 & 19 \\
\hline A showdown agreement between Turkey and EU & 31 & 20 & 33 \\
\hline An unsuccessful agreement for $E U$ & 17 & 3 & 13 \\
\hline An agreement difficult to apply in practice & 10 & 18 & 11 \\
\hline An agreement not beneficial for refugees & 7 & 20 & 11 \\
\hline A problematic agreement in terms of law and ethics & 14 & 7 & - \\
\hline A self-abnegation agreement for Turkey & 7 & 1 & - \\
\hline Other & 4 & 2 & 2 \\
\hline Total & 100 & 100 & 100 \\
\hline
\end{tabular}

\section{AN AGREEMENT ON VISA LIBERALIZATION FOR EU}

In all three newspapers, it is seen that the agreement is mainly framed as an agreement which will ensure visa-free transit to European Union. However, this framing is growing up upon speeches that differ and conflict in themselves.

A Successful Agreement for Turkey: It is a framing that views the agreement as a benefit or an achievement for Turkey. It is highlighted that visa-free travel to Europe, which Turkey has waited for many years, is about to be realized, thanks to the agreement. The agreement which will make Turkey's wishes about visa-free travel to Europe come true is also shown as an international success. Within this framework which is mainly used by the authorities of the government party AKP, the agreement is also described as "a present from AKP to Turkish citizens", too. The then prime minister Ahmet Davutoğlu, Minister of European Union Volkan Bozkır and Minister of Foreign Affairs Mevlut Çavuşoğlu come to the fore among the names that are framing the agreement in this way. It is also 
pointed out that the agreement cannot be applicable if EU does not keep its "promise about visa liberalization". In context of this framing, some procedural information is also given about the visafree travel such as the start date of it, the kind of passport that will be used or the countries to be included.

A Showdown Agreement between Turkey and EU: This framing includes the discussions about the revision of the anti-terrorism law of Turkey which is one of the criteria that Turkey should fulfil in order to the visa liberalization being put into practice. The discussions especially concentrated on the revision of the definition of terror according to the EU standards. In this context freedom of speech, freedom of the press and other fundamental freedoms are debated in relation to terrorism. Turkish antiterrorism law is presented as a tension and showdown subject between the EU and Turkey. Turkish government shaped the discussions upon the fact that the requested changes in the anti-terrorism law do not match the national interests as Turkey is a country under heavy terrorist threat. It is pointed out that antiterrorism is a vital issue for Turkey and if necessary Turkey can give up implementing it. In this direction Turkish President Recep Tayyip Erdoğan's words "Sorry, but we will not change anything when we are under terror attack", which were said against EU's request for a change in antiterrorism law in order to allow visa liberalisation", can be given as an example to this framing. The other side of the discussion EU, however, says that Turkey "threatens EU to sic the refugees on them" instead of meeting the criteria and that they will not compromise on this issue. The EU upholds the showdown by expressing those fundamental freedoms especially freedom of speech cannot be the subject of any political bargain.

An Unsuccessful Agreement for $\boldsymbol{E U}$ : In this framing which defines the agreement as a failure for EU two different failures are mentioned: The first one is an argument that is used in some EU countries especially by the members of some conservative and nationalist opposition parties. According to this argument, "visa liberalisation will cause the invasion of Europe by Turks", "the terror threat will be brought by refugees", and "the ISIS threat will increase within the borders of Europe". The one who is responsible for the refugee agreement which is "nearly inoperative", "problematic" and "unsuccessful" is usually shown as German Prime Minister Angela Merkel. Turkish Government's reticent attitude about the fulfilment of the criteria regarding anti-terror law is described as "Turkey's twisting Merkel and EU around its finger."

The second failure definition is being formed upon a speech which is about the fact that EU is betraying its own ideals and values. It is a framing which is usually used by some organizations such as Amnesty International and some opposition parties in EU. For the reasons of failure, it is put forward that with this agreement EU "ignores the problems about freedom of thought and freedom of the press in Turkey" and that "although everybody has the right of asylum within the borders of EU, EU makes an agreement that is violating this understanding. Besides, it is claimed that EU becomes dependant on Turkey with this agreement.

\section{AN AGREEMENT NOT BENEFICIAL FOR REFUGEES}

It is a framing that has a critical attitude toward the deal and is mainly used by national and international NGO, rights groups, community volunteers, and refugees/migrants. The agreement is described as a regulation that has brought negativities to refugees/migrants. It's emphasized that the refugees were not welcomed in the areas where refugees camps are established, they were exposed to fascist demonstrations and attacks, the conditions while sending them back and the conditions of refugee camps were inhuman, and there were inadequacies of very basic conditions such as food, sheltering, health and cleaning.

Examples of official negativities that the refugees encountered can be given as; "deliberately preventing the asylum applications of the refugees by the Greek officers (The Greek Police is blamed for changing the documents of the asylum request of the refugees)" and "mistakenly sending back the refugees that applied for asylum and eligible for asylum." The risk of encountering death that the refugees sent back to have to face, suicides of some refugees that were afraid of being sent back are among some examples that the agreement brought forth. Saddening break-up stories of family 
members or friends that went to Greece right before and after the agreement took effect as of 20 March, are narrated. Other mentioned examples are unjust treatments and insecure situations that helpless refuges experienced -such as prostitution, black market and drugs cases- because of insufficient security in refugee camps, closing the repatriation centres to control of NGO or other civil organizations, abusements of refugees or immigrants by human smugglers such as misinforming or not informing them about the agreement with an intent to defraud.

\section{A PROBLEMATIC AGREEMENT IN TERMS OF LAW AND ETHICS}

The agreement is framed as being not lawful and ethical both for its content and its application. In the discussion about the fact that the agreement is not legal, it is especially emphasized that the principal of sheltering the ones, who escape the battle, is violated. Among the issues that are presented as illegal, unethical and dishonourable some examples are given such as; sending only the Syrian refugees to EU from Turkey but not including Iraqian or Afghan refugees, Turkey's not having the statute of being a secure country, Greece's old and insufficient sheltering and law system, negative treatments to refugees during the implementation of the agreement, -eg. the Frontex officers faces were covered with hygiene masks, the refugees sent to Turkey were handcuffed to each other by plastic handcuffs in groups of two while they were getting on the ferry. This frame, which is shaped by the comments of actors inside and outside of Turkey, also includes the criticism that "the refugees are seen as an interchangeable property" and human dignity is being trampled on. This frame is used by organizations such as Council of Europe, Office of the United Nations High Commissioner for Refugees and Amnesty International and some Turkish rights groups.

\section{SELF-ABNEGATION AGREEMENT FOR TURKEY}

It is a framing that includes the criticisms of the agreement by opposition parties in Turkey in general. Especially the opposition party members who have a nationalist and right-wing tendency framed the agreement as " a non-resistance for Turkey" and that it is against the national interests. Accordingly, the agreement is seen as a regulation that officially made Turkey "the refugee collection centre of all Europe". Although the agreement is seen as a failure for Turkey, it is seen as a success for "EU that tries to keep out the humanitarian plight of the refugees from its borders". On the other hand, it is seen that not only the right-wing or conservative opposition parties, but also some other opposition parties in Turkey frames the agreement as an unsuccessful attempt. This time, however, the claims that put forward for showing the agreement as a failure for Turkey differ at some degree. The agreement is described as a very big self-abnegation for Turkey both economically and socially. The agreement is criticized as the established refugee camps in Turkey cannot provide a healthy and peaceful environment for the refugees and also they cause some huge problems that the local people, who are living around the camping areas, cannot cope with. In the criticisms the burden is laid on both EU and AKP. AKP is criticized for "transforming Turkey to a refugee prison for 3 billion dollars." It is reminded that no other country accepted as many refugees as Turkey and, EU is criticized as Turkey was not supported sufficiently for dealing with the problem of refugees and that it was left alone; It is impossible for Turkey to cope with 3 million refugees because either Turkey nor another country has the capacity or a system to handle such a large population of refugees. Turkey has its limits.

\section{AN AGREEMENT DIFFICULT TO APPLY IN PRACTICE}

It is framing that is made by the officers, attendants or community volunteers who take a part in implementation process of the agreement in both Turkey and Greece. An emphasis is prevalent on the fact that there has been a state of chaos after the agreement came into force. As one of the main reasons of the chaos, it is highlighted that the agreement was put into force very quickly without making the necessary preparations. Inefficacies and deficiencies about substructure and logistics such as the staff, building, health services, transportation, communication, security, translation etc. are pointed out. The agreement is also shown as a regulation that is impossible to be applied as it places a burden on Turkey and Greece which is not possible to carry. The speech about the inapplicability of the agreement is strengthen by examples such as the tension created by the involuntary return of refugees to Turkey, refugee demonstrations and protests, emergence of events about drugs, prostitution and black-market around the refugee camps. Furthermore, there are also some emphases that strengthen the fact that this agreement will not give results in practice such as the collective 
asylum request of Syrian refugees, who do not want to be sent back to Greece, or human smugglers' tendency to go towards other routes after the beginning of return process.

\section{CONCLUSION}

In the analysed news, it is seen that the frames being used by the representatives of Turkey and EU are predominant. The most common definitions, comments or evaluations about the agreement belong to policy-making actors from Turkey and EU who have taken place in the formation of the agreement. The opposite is true for refugees and migrants who have the lowest presence in the news. The weak presence of refugees and migrants' voices in the coverage of the agreement seems as a problem because it shows that the online press has failed to make the refugees' voices heard in the Turkish public sphere.

It can be claimed that this situation is because of the fact that the journalists cannot interact with the refugees due to some reasons such as language barrier or physical obstacles. However, there is also a low visibility ratio of actors from NGO's such as rights groups, who could be the voice of the refugees' emotions, thoughts and experiences about the agreement as well as reporting the problems and violation of refugees' rights. A similar tendency is also determined in defining and interpreting the agreement in the news. The agreement is mainly defined as an event, which will provide Turkish nationals with visa-free travel to EU countries.

The dominant discussions about the agreement are also formed around the topic of "visa liberalization promise to Turkey". In this direction, the discussions about the criteria for the "revision of antiterrorism law" by Turkey which is required for "visa liberalization" are the most prominent topic in the news. In this context, freedom of speech, freedom of press and other fundamental rights are debated especially in relation to terrorism. In this context, the agreement is presented as an issue of tension between the EU and Turkey. The frames used by Turkish government officials that includes discourses that the requested changes in the anti-terrorism law do not match the national interests as Turkey is a country under heavy terrorist threat, shaped the discussions.

However, the discourses that have discussions or criticisms towards the core or application of the agreement (if it is ethical, legal or not) remain in the background. Sending only the Syrian refugees to EU from Turkey but not including Iraqian or Afghan refugees, Turkey's not having the statute of being a secure country, Greece's old and insufficient sheltering and law system, negative treatments to refugees during the implementation of the agreement are given as examples for some issues that are presented as illegal, unethical and dishonourable.

Comments and evaluations regarding the meaning of the agreement for the life and the future of the refugees are also very few. The frames that includes examples of problems that the refugees have experienced such as suicides, saddening break-up stories of family members or friends, prostitution, black market and drugs cases (because of insufficient security in refugee camps) have a low visibility. Similarly, there are only a few discussions that discuss the fact of migration in its own dynamics and present and define the agreement around these dynamics.

As a result, it is seen that the argument is dominantly framed in a way to serve Turkey's and EU's own agenda. Within this scope, the agreement is once more defined on the basis of the primary issues about the relations between Turkey-EU and the internal affairs of EU countries. Since most of those problems and debates are not directly related to the issue of migration, it could be said that the coverage of the deal was overshadowed by them.

\section{REFERENCES}

Baum, M.A. and Potter, P.B.K. (2008). "The Relationships Between Mass Media, Public Opinion, and Foreign Policy: Toward a Theoretical Synthesis”, Annual Review Political Science: 11:39-65. https://www.hks.harvard.edu/fs/mbaum/documents/BaumPotter_AnnualReview2008.pdf Accessed $10 / 03 / 2017$. 
Benford, R.D. and Snow, D.A. (2000). "Framing Processes and Social Movements: An Overview and Assessment". Annual Review of Sociology, Vol. 26 (2000): 611-639.

Bennett W.L, Lawrence R.G and Livingston S. (2006). "None Dare Call it Torture: Indexing and the Limits of Press Independence in the Abu Ghraib Scandal". Journal of Communication, 56(3):467-85. Berry, M., Garcia-Blanco, I. and Moore, K. (2015). Press Coverage of the Refugee and Migrant Crisis in the EU: A Content Analysis of Five European Countries. Report prepared for the United Nations High Commission for Refugees, http://www.unhcr.org/56bb369c9.pdf Accessed 25/03/2017. Brody, R.A. (1991). Assessing the President: The Media, Elite Opinion, and Public Support. Stanford, CA: Stanford Univ. Press.

Chalaby, J. (1998). The Invention of Journalism. London: Palgrave Macmillan.

Ekinci M.U. (2016).Türkiye-AB Muafiyeti Süreci ve Geri Kabul Anlaşması Hakkında Temel Sorular ve Yanitlarl, Ankara: TC Avrupa Birliği Bakanlı̆̆l, http://www.ab.gov.tr/49332.html Accessed: $12 / 02 / 2017$.

Gamson, W. A. \& Wolfsfeld, G. (1993). "Movements and media as Interacting Systems". Annals of the American Academy of Political and Social Science, 28(5): 114 - 125.

Gerhards, J. and Schafer, M.S. (2010). "Is the internet a better public sphere? Comparing old and new media in the USA and Germany". New Media and Society, 12(1): 143-160.

Graber D.A. (2002). Mass Media and American Politics. Washington, DC: CQ Press.

Hall, S. (1997). Representation: Cultural Representations and Signifying Practices. London: Sage. Hall, S. (1980). "Encoding/decoding”. In: Centre for Contemporary Cultural Studies (Ed.): Culture, Media, Language: Working Papers in Cultural Studies, 1972-79 London: Hutchinson:128-38. lepo.it.da.ut.ee/ cect/teoreetilised\%20seminarid_2010/...seminar/Hall,\%20S.doc Accessed 20/02/2017.

Holsti O.R. (2004). Public Opinion and American Foreign Policy. Ann Arbor: University of Michigan Press.

Jentleson B.W. (1992). "The Pretty Prudent Public-Post-Vietnam American Opinion on the Use of Military Force", International Studies Quarterly, 36(1):49-74.

Kuypers J.A. (1997). Presidential Crisis Rhetoric and the Press in the Post-Cold War World. Westport, CT: Praeger.

Nacos, B.L, Shapiro R.Y, and Isernia P. (2000). Decisionmaking in a Glass House. New York:

Rowman \& Littlefield.

Paletz, D.L. (2002). The Media in American Politics. New York: Longman

Statham, P. and Trenz, H.J. (2013).The Politicization of Europe: Contesting the Constitution in the Mass Media. London and New York: Routledge.

Sirkeci, I. (2017). “Turkey's Refugees, Syrians and Refugees from Turkey: A Country of Insecurity”, Migration Letters, 14(1): 127-144.

Zaller J. and Chiu D. (2000). "Government's Little Helper: U.S. Press Coverage of Foreign Policy Crises, 1946-1999”. In: B.L. Nacos, R.Y. Shapiro and P. Isernia, (eds.) Decisionmaking in a Glass House, New York: Rowman \& Littlefield. 